\title{
ON THE DISTRIBUTION OF ABERRANT FORMS OF CHITINOZOANS IN THE SILURIAN OF ESTONIA AND WEST LATVIA
}

Polymorphism or the so-called aberrant or teratological forms of chitinozoans have repeatedly been a subject of discussions (Taugourdeau, Magloire, 1964; Eisenack, 1968, 1972; Cramer, Diez, 1970, 1974; Paris, 1981 ; etc.). In this paper the author has used the word aberrant as a convenient, rather general term for denoting different deviations in the morphology of chitinozoan vesicles, exceeding the limits of variability. Cramer and Diez (1970) have interpreted most of aberrant vesicles as rejuvenating stages in vegetative reproduction of chitinozoans.

According to Cramer and Diez (1974) aberrant forms are regionally biased. In the Silurian they were quite common in the areas of higher paleolatitudes, but exceptionally rare in the lower latitudes, occurring more frequently in sandy-silty terrigenous rocks than in limestones. So far aberrant forms have been recorded from some areas of Africa (Tunisia, Libya) and Florida approximately at the rate of one per thousand "normal" specimens (i. e. $0.1 \%$ ). Usually this ratio is considerably lower, constituting about one aberrant specimen per ten to twenty thousand "normal" ones (Cramer, Diez, 1974).

\section{Plate I}

Figs. 1-3. Margachitina margaritana (Eisenack); 1 - aberrant vesicle Ch 187/1905, Ruhnu boring, depth $407.3 \mathrm{~m}$, Jaggarahu Stage, Jamaja Formation, $\times 250 ; 2$ - aberrant chain Ch 166/1831, Ruhnu boring, depth $404.2 \mathrm{~m}$, Jaagarahu Stage, Jamaja Formation, $\times 250$; 3 - aberrant chain Ch 149/1948, Ohesaare boring, depth $305.4 \mathrm{~m}$, Jaani Stage, Paramaja Member, $\times 160$. Figs. 4, 5. Desmochitina sp., aberrant chains, Ruhnu boring, depth $406 \mathrm{~m}$, Jaagarahu Stage, Jamaja Formation; 4 - Ch 188/1849, $\times 250 ; 5-$ Ch 183/1749, $\times 160$. Fig. 6. Desmochitina? sp., aberrant chain Ch 190/1905, Ruhnu boring, depth $407.35 \mathrm{~m}$, Jaagarahu Stage, Jamaja Formation, $\times 250$. Fig. 7. Ancyrochitina sp., with strongly elongated neck, Ch 191/1831, Ruhnu boring, depth $404.2 \mathrm{~m}$, Jaagarahu Stage, Jamaja Formation, $\times 100$. Fig. 8. Ancyrochitina cf. ancyrea (Eisenack), vesicle $\mathrm{Ch} 192 / 1551$ with elongated neck, Kipi boring, depth $116.8 \mathrm{~m}$, Jaani Stage, Ninase Formation, $\times 310$.

Plate II

Fig. 1. Ancyrochitina sp., aff. convexa Nestor, vesicle with strongly elongated neck, $\mathrm{Ch}$ $518 / 9650$, Ventspils boring, depth $827.6 \mathrm{~m}$, Adavere Stage, Jurmala Formation, $\times 340$. Fig. 2. Ancyrochitina sp., cf. pachyderma Laufeld, vesicle with strongly elongated neck Ch 519/9431, Ventspils boring, depth $762 \mathrm{~m}$, Jaani Stage, Riga Formation, $\times 145$. Fig. 3. Linochitina sp., underdeveloped chain Ch 520/9458, Ventspils boring, depth $708 \mathrm{~m}$, Jaagarahu Stage, Riga Formation: $3 a-\times 290,3 b-$ the spongy girdle on the body wall at the connection of two underdeveloped vesicles, $\times 1100$. Fig. 4. Conochitina cf. visbyensis Laufeld, aberrant chain Ch 521/10667, Jaagarahu boring, depth $44.6 \mathrm{~m}$, Jaani Stage, Mustjala Formation, $4 a-\times 495,4 b-$ the connection of two vesicles, $\times 2500$. Fig. 5 . Cyathochitina? sp. aberrant chain $\mathrm{Ch} 522 / 897$, Ohesaare boring, depth $441.5 \mathrm{~m}$, Juuru Stage, Ruja Member: $5 a-\times 315,5 b-$ basal part with a scar, $\times 720$. Fig. 6 . Chitinozoa gen. et sp. indet, Ch 523/1055, Kirikuküla boring, depth $47.9 \mathrm{~m}$, Adavere Stage, Rumba Formation, $\times 600$.

* Eesti Teaduste Akadeemia Geoloogia Instituut (Institute of Geology, Estonian Academy of Sciences). 200105 Tallinn, Estonia pst. 7. Estonia. 
PLATE I
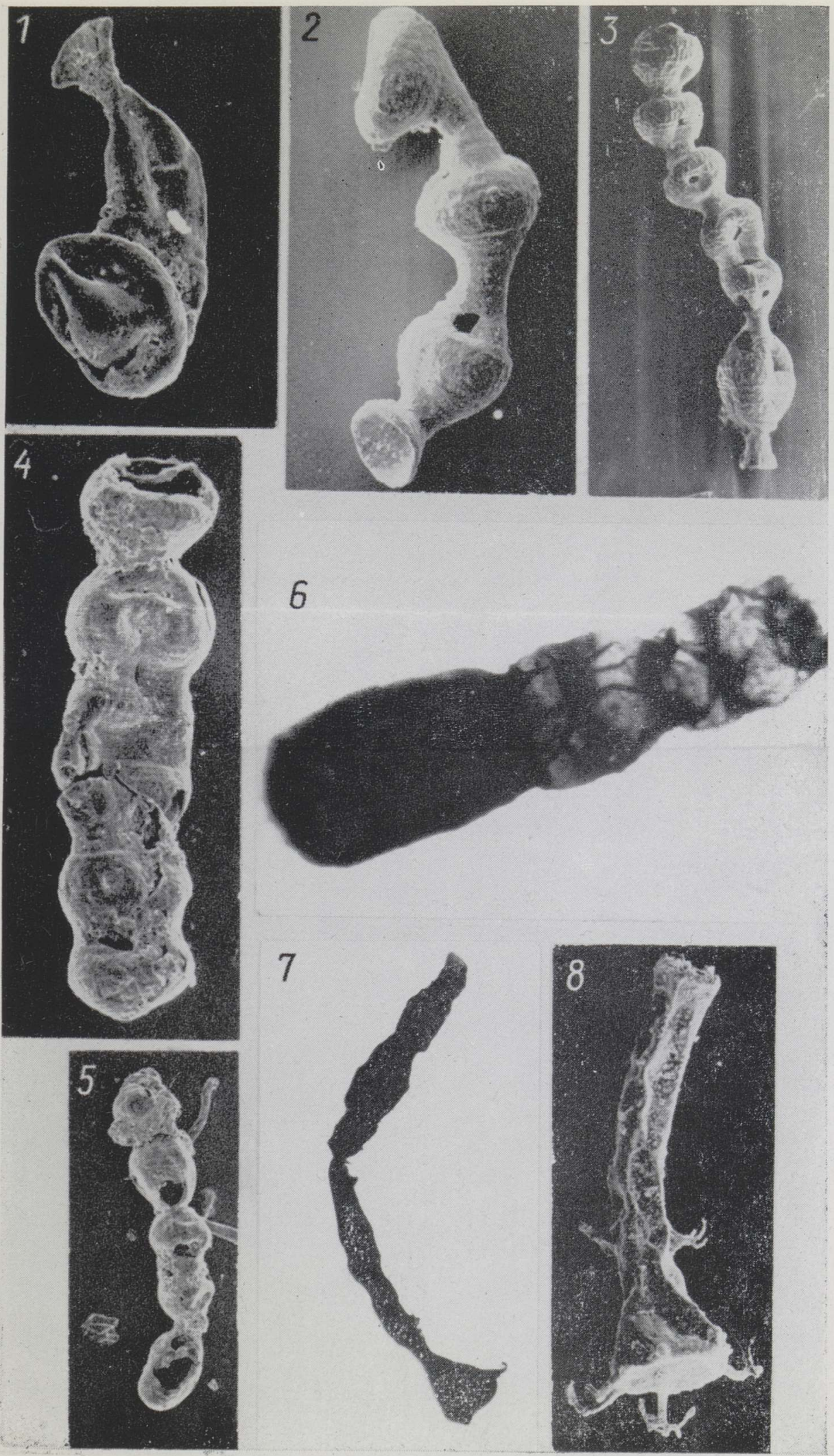
PLATE II
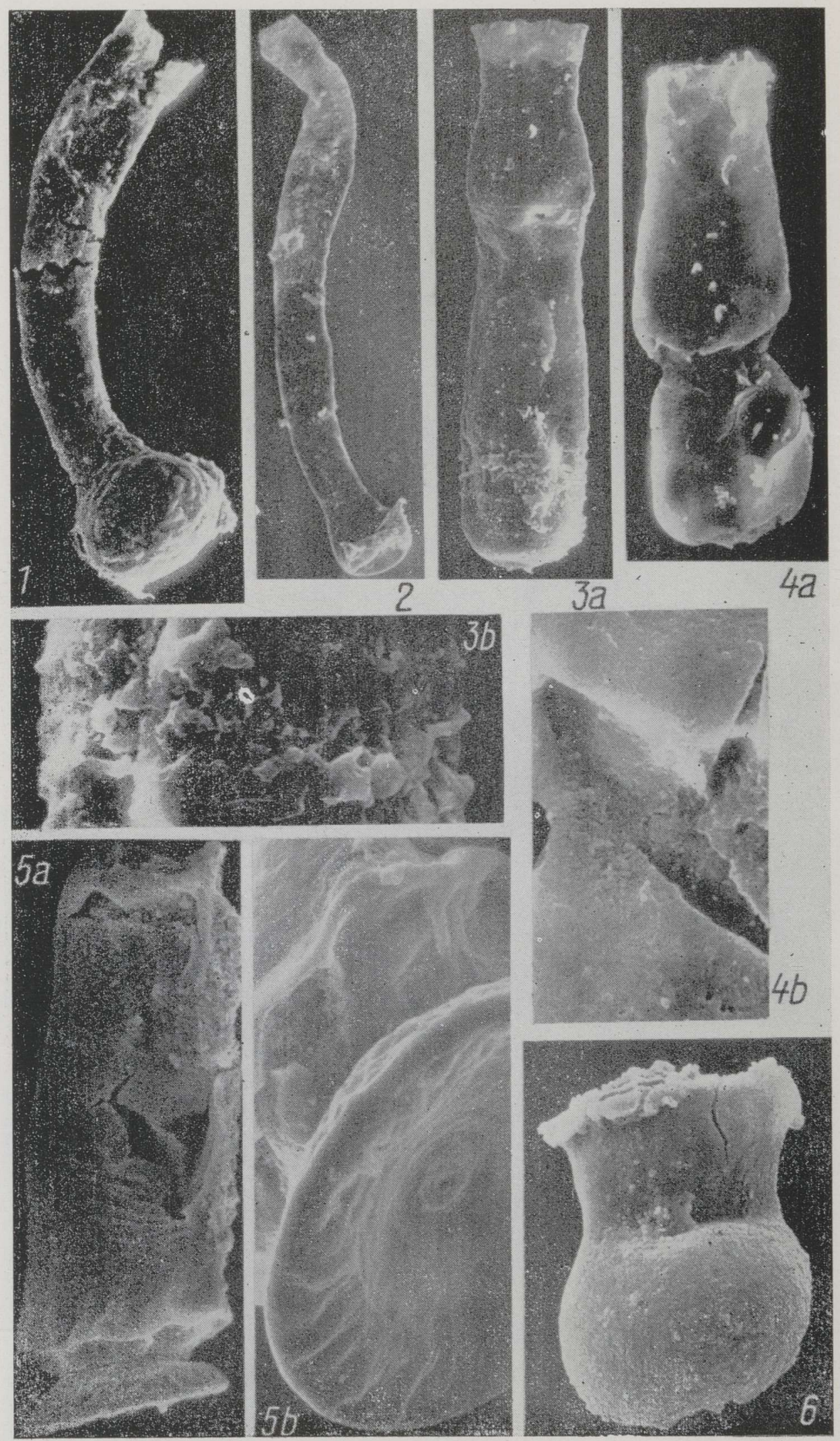
FLATE III

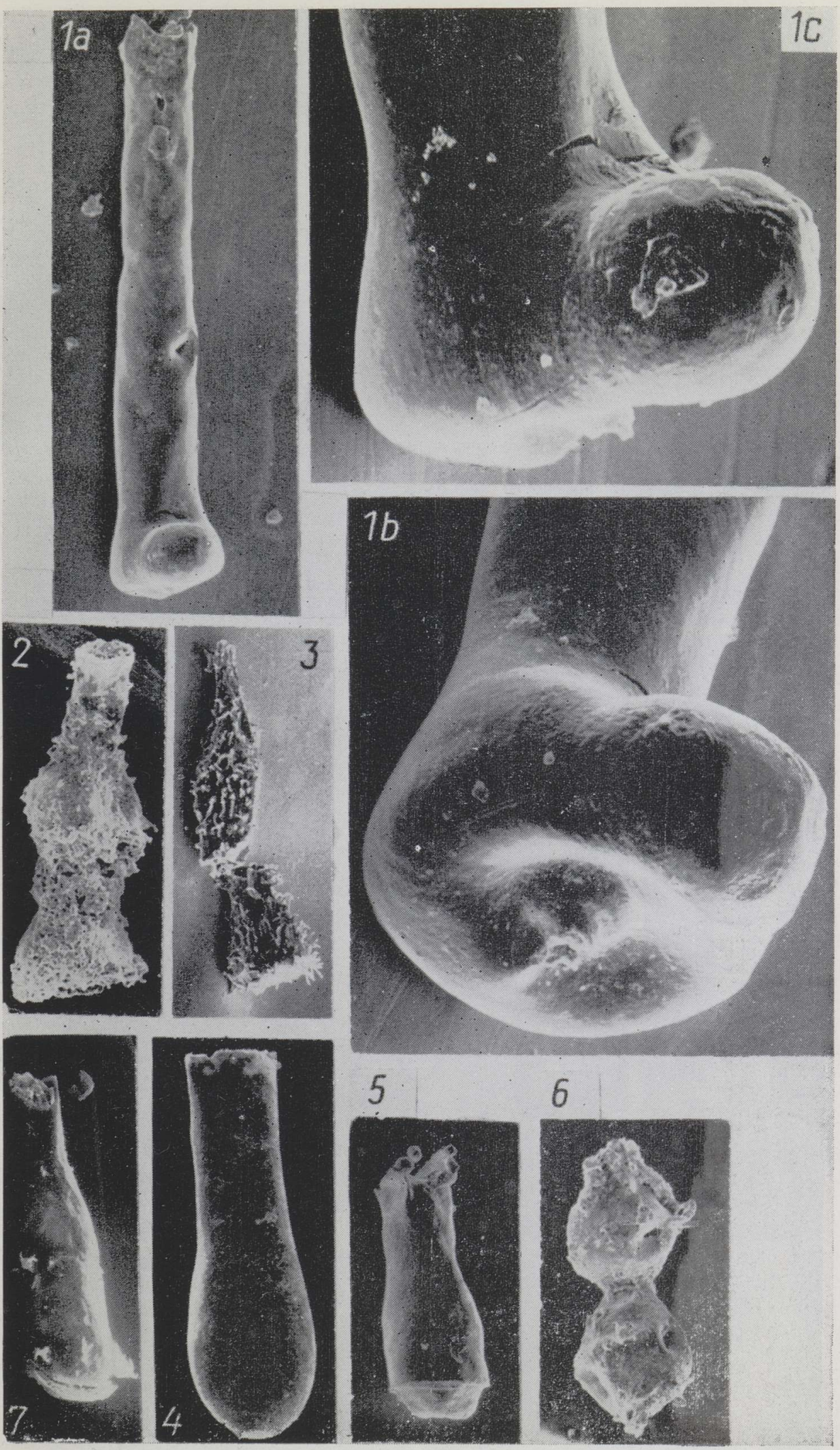




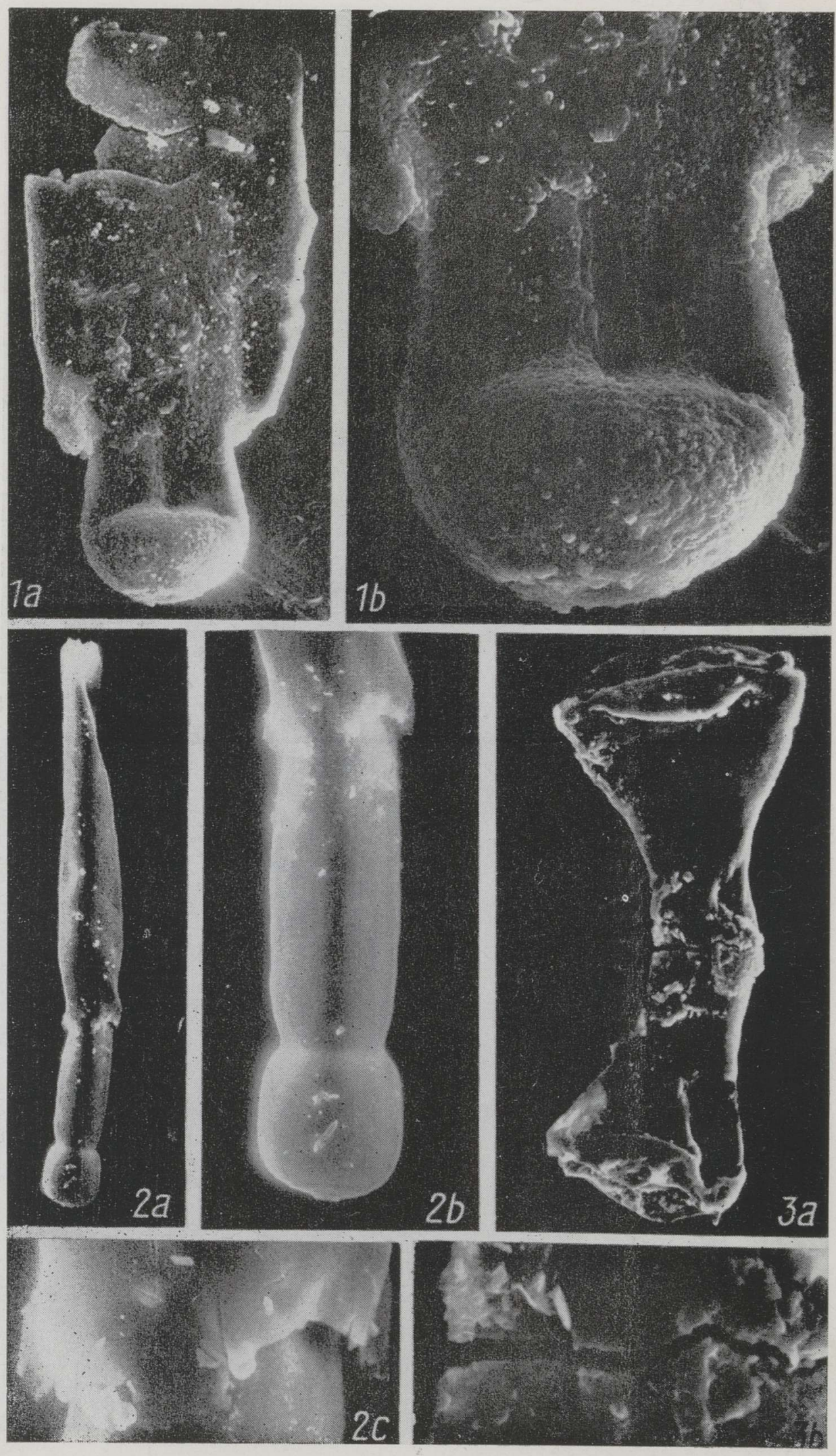


Laufeld (personal comm.) has mentioned that aberrant forms of chitinozoans are extremely rare in the Silurian sediments of Gotland, but also in other areas of Sweden. Eisenack (1972) reported only three aberrant specimens among several tens of thousands "normal" ones from the erratics. These data enabled Cramer and Diez (1974) to consider the Baltic region as an area of "structurally sound colonialism of chitinozoans".

However, in the Ruhnu core section in the lower middle Wenlock of South-West Estonia aberrant forms are more frequent than in the abovementioned regions (see Нестор, 1984), with on the average two to three aberrant specimens per one thousand "normal" ones $(0.2-0.3 \%)$, but in some levels even up to $1 \%$.

These are mostly aberrant chains of the so-called "telescopic colonies" (according to Cramer, Diez, 1974), in which separate vesicles of the chain are underdeveloped and irregular, and internal and external structures (prosome, cingulum, etc.) are often missing (Plate I, Figs. 2-6; Plate II, Fig. 3).

Besides, there occur chains or twins of ordinarily single vesicles, e. g. representatives of the genera Ancyrochitina and Goilandochitina. In such twins one of the vesicles is usually more developed than the other. Often the neck of the lower vesicle is underdeveloped, being short and thick (Plate III, Fig. 2). Extremely rare are chains of Conochitina, characterized by pronounced polymorphism (Plate II, Fig. 4; Plate IV, Fig. 2). Rather frequent are aberrant vesicles with a more or less swollen neck (Plate III, Fig. 3) and elongated chamber (Plate I, Fig. 1; Plate III, Fig. 7), but those with a swollen basal edge (Plate III, Fig. 1) are rare. Chains consisting of two individuals joined by oral openings (Plate IV, Fig. 3) are very rare.

A frequent type of aberrance is gigantism (according to Cramer, Diez, 1974). Gigantic forms have usually a strongly elongated neck. This phenomenon is rather common in ancyrochitinides (Plate I, Figs. 7, 8; Plate II, Figs. 1, 2), but also in the representatives of the genus Conochitina having unusually long vesicles.

A particular group comprises aberrant forms with uncertain generic characteristics (Plate III, Fig. 6; Plate II, Fig. 6; Plate IV, Fig. 1). Tentatively also vesicles of chitinozoans with an underdeveloped highly convex or swollen base without aboral structures (Plate III, Figs. 4, 5) can be considered as aberrant forms.

\section{Plate III}

Fig. 1. Conochitina cf. mamilla Laufeld, with the protuberance at the basal edge of the vesicle, Ch 193/9211, Ninase cliff, Jaani Stage, Ninase Formation: $1 a-\times 250,1 b-$ $\times 1360,1 c-\times 360$. Fig. 2. Gotlandochitina cf. martinssoni Laufeld, underdeveloped chain Ch 194/1763, Ruhnu boring, depth $361.9 \mathrm{~m}$, Jaagarahu Stage, Jamaja Formation, $\times 250$. Fig. 3. Gotlandochitina martinssoni Laufeld, with strongly bulged neck, Ch $195 / 1580$, Ohesaare boring, depth $247.5 \mathrm{~m}$, Jaagarahu Stage, Jamaja Formation, $\times 250$. Fig. 4. Conochitina sp., with underdeveloped base Ch 196/1591, Oliesaare boring, depth $202.85 \mathrm{~m}$, Jaagarahu Stage, Jamaja Formation, $\times 165$. Fig. 5. Linochitina cingulata (Eisenack), with bulged base Ch 197/1580, Ohesaare boring, depth $247.5 \mathrm{~m}$, Jaagarahu Stage, Jamaja Formation, $\times 440$. Fig. 6. Ancyrochitina? sp., aberrant twins $\mathrm{Ch} 198 / 9492$, Kihnu boring, depth $179.6 \mathrm{~m}$, Jaani Stage, Ninase Formation, $\times 310$. Fig. 7 . Ancyrochitina sp., aberrant twins Ch 517/1940, Vängla outcrop, Adavere Stage, Rumba Formation, $\times 250$.

\section{Plate IV}

Fig. 1. Chitinozoa gen. et sp. indet, aberrant vesicle Ch 524/10361, Nagli boring, depth $631 \mathrm{~m}$, Adavere Stage, Jurmala Formation: $1 a-\times 245,1 b-\times 630$. Fig. 2. Conochitina sp., aberrant chain Ch 525/10676, Jaagarahu boring, depth $35.7 \mathrm{~m}$, Jaani Stage, Mustjala Member: $2 a-\times 100,2 b-$ underdeveloped vesicles in chain, $\times 23,2 c-$ the ripped base of the vesicle, $\times 650$. Fig. 3. Ancyrochitina sp., aberrant twins $\mathrm{Ch} 526 / 9379$, Adavere Stage, Jurmala Formation: $3 a-\times 450,3 b-$ connection of two vesicles, $\times 1750$. 
Aberrant specimens have been recorded from almost all Silurian regional stages of Estonia and West Latvia, but in this paper materials from the lower Silurian sections (based on about 2,500 studied samples) are discussed.

Aberrant chitinozoans are more numerous in argillaceous rocks: in the Wenlock marlstones of the Paramaja and Jamaja formations in South Estonian sections (Ruhnu, Ohesaare) and in mudstones of the Jurmala and Riga formations in the Ventspils core of West Latvia (approximately $0.1 \%$ ). The calcareous-terrigenous rocks of these formations have much greater thickness than coeval carbonate sediments in the marginal part of the sedimentary basin (see Nestor, Einasto, 1982, Fig. 2), which confirms their comparatively rapid accumulation.

On the other hand, aberrant specimens are the most numerous in the Ruhnu core section in the middle Wenlock in boundary beds of the Jaani and Jaagarahu stages (see Нестор, 1984, Fig. 2). Approximately at the same level aberrant forms (mostly Ancyrochitina chains) have been recorded in many other core sections - Ohesaare, Kipi, Kihnu, Kingissepa, Varbla, and Tõlla. This stratigraphic level roughly coincides with the beginning of the regressive phase in the development of the Baltic Silurian basin (Эйнасто, 1986; etc.). Another level yielding aberrant chitinozoans more frequently occurs in the Ohesaare core section in the middle part of the Jaagarahu Stage where marlstones of the Jamaja Formation were replaced by nodular limestones of the Sõrve Formation. Such lithological transition in the shallowing-up sequence obviously corresponds to another break in the regressive development of the sedimentary basin.

The above-said suggests that the occurrence of aberrant chitinozoans in the Silurian sections of Estonia and West Latvia is not exceptional, but their distribution was environmentally controlled. In the conditions of stable continuous sedimentation of carbonates, aberrant forms were very scarce. On the other hand, at the period of regression and relatively rapid accumulation of terrigenous sediments much more aberrant vesicles were formed, making about $0.2-0.3 \%$ of the whole chitinozoan population. This confirms the position of Cramer and Diez (1974) on the dependence of aberrant forms of chitinozoans on the type of sediment, but contradicts their opinion on the occurrence of aberrant forms mostly at high paleolatitudes and their extreme rareness at low latitudes, as in the Baltic region.

Actually, the records of aberrant forms of chitinozoans in the Baltic area have been so rare for the reason that Silurian outcrops are mainly characterized by carbonate rocks, but for the most part subsurface terrigenous rocks were practically unstudied until last decades.

Finally, one probable explanation of aberrance of chitinozoans may be related to their vegetative reproduction. If it took place (at least partly) in benthic conditions, then more rapid accumulation of sediments could prevent and interrupt the normal process of reproduction and generate aberrant vesicles. 
Cramer, F. H., Diez, M. 1970. Rejuvenation of Silurian chitinozoans from Florida. Rev. Esp. Micropal., 2, 45-54.

Cramer, F. H., Diez, M. 1974. Polymorphism in Silurian chitinozoans from Tunisia. Palaeontographica, Abt. B, 148, $1-8$.

Eisenack, A. 1968. Uber Chitinozoen des Baltischen Gebietes. - Palaeontographica, Abt. A, $131,137-198$.

Eisenack, A. 1972. Beiträge zur Chitinozoenforschung. - Palaeontographica, Abt. A, $140,117-130$.

Nestor, H., Einasto, R. 1982. Application of the shelf and slope concepts to the Silurian Baltic Basin. - In: Ecostratigraphy of the East Baltic Silurian. D. Kaljo, E. Klaamann (eds.). Tallinn, 17-23.

Paris, F. 1981. Les Chitinozoaires dans le Paléozoique du Sud-Ouest de l'Europe. Mém. Soc. géol. minéral. Bretagne, 26.

Taugourdeau, Ph., Magloire, L. 1964. Le dimorphisme chez les Chitinozoaires. - Bull. Soc. Géol. Fr., 6, 674-677.

Нестор В. 1984. Зональное распределение хитинозой в яаниском горизонте (венлок Эстонии) и проблема его границ. - In.: Стратиграфия древнепалеозойских отложений Прибалтики. Таллинн, $119-127$.

Эйнасто Р. Э. 1986. Основные стадии развития и фациальные модели силурийского краевого бассейна Балтики. - In.: Теория и опыт экостратиграфии. Д. Л. Кальо, Э. Р. Клааманн (eds.). Таллинн, $37-54$.

Presented by A. Raukas

Received

Dec. 27,1990

Viiu NESTOR

\section{KITINOZOADE HÄLBELISTE VORMIDE LEVIKUST EESTI JA LÄANE-LÄTI SILURIS}

On antud ülevaade kitinozoade hälbeliste vormide levikust Eesti ja Lääne-Läti alamsiluri läbilōikes ning võrreldud seda teadaolevate andmetega teistest regioonidest. Hälbeliste vormide kujunemine on seotud põhiliselt vegetatiivse paljunemisega, kusjuures olulist osa on etendanud settimistingimused ja sette tüüp.

\section{Buǔy HECTOP}

\section{О РАСПРОСТРАНЕНИИ АБЕРРАНТНЫХ ФОРМ ХИТИНОЗОЙ В СИЛУРЕ ӘСТОНИИ И ЗАПАДНОИ ЛАТВИИ}

Рассматривается распространение различных аберрантных форм хитинозой в нижнем силуре Северной Прибалтики. Изученный материал (2500 проб) подтверждает связь аберрантных форм с типом отложений. В терригенных и карбонатно-глинистых породах их относительное содержание близко к максимальным показателям в других регионах мира (Флорида, Ливия). В условиях медленной стабильной седиментации карбонатных осадков аберрантные формы образуются очень редко, а во время регрессии и относительно быстрого накопления терригенных осадков - гораздо чаще. Одна из причин появления аберрации у хитинозой может быть связана с их вегетативным размножением. В бентосных условиях более быстрое накопление отложений могло прервать нормальный процесс размножения и стать причиной образования отклоняющихся везикул хитинозой. 